\title{
Reactivity of Supported Nickel Catalysts Prepared by Gas Phase Methods
}

\author{
Yoshimitsu Uemura*, Yasuo Hatate, and Atsushi Ikari \\ Department of Chemical Engineering, Faculty of Engineering, \\ Kagoshima University, 21-40, Kohrimoto 1-chome, Kagoshima 890
}

(Received March 7, 1988)

\begin{abstract}
Studies on nickel/alumina catalysts, prepared by deposition of nickel chloride vapors on spherical alumina ( $3.5 \mathrm{~mm}$ diameter) and by gas phase reduction of nickel chloride vapors, were undertaken to investigate the effects of the methods of preparation, including impregnation, on the catalytic properties. The rate of benzene hydrogenation per unit surface area of nickel particle (calculated from the nickel content and surface mean diameter of nickel) on the catalyst prepared by gas phase reduction was not so different from that prepared by impregnation; whereas the rate of hydrogenation observed on the catalyst prepared by vapor deposition was from 3 to 8 times greater than the catalyst prepared by impregnation. This seems to be caused by the characteristics of the nickel particles resulted from vapor deposition, i.e., deposition makes the surface uneven or brings about higher activity per unit surface area of nickel. Cyclohexene showed the following order of selectivity: vapor deposition > gas phase reduction> impregnation.
\end{abstract}

\section{Introduction}

Such preparation methods as impregnation or precipitation carried out in the liquid phase are common industrial ones for preparing supported metal catalysts. Recently, a gas phase method using precursor vapors has attracted attention with the development of the CVD technique by which useful materials such as membranes and fine particles ${ }^{1)}$ can be produced. In the liquid phase method, catalytic precursors in liquid phase are used. In the gas phase method, on the other hand, vapors of the catalytic precursor are used; therefore, new catalytic properties can be expected for the catalysts prepared by this gas phase method. In fact, some workers have reported higher catalytic activities ${ }^{2), 3)}$ and selectivities ${ }^{4)}$ of the catalysts prepared by gas phase method compared with those prepared by conventional methods.

In this work, studies on nickel/alumina catalysts prepared by deposition of nickel chloride vapors on alumina (vapor deposition method) and gas phase reduction were undertaken to investigate the effects of the methods of preparation on the catalytic properties. The results obtained from the gas phase method were also compared with those obtained from the impregnation method in our previous studies, in which we have investigated such effects as the nature of the sup-

* To whom correspondence should be addressed. port, ${ }^{6,77,8)}$ the nickel content, ${ }^{5), 7), 9)}$ the solvent of impregnant, ${ }^{7)}$ the source of nickel, ${ }^{9)}$ and postimpregnation drying conditions ${ }^{5,6), 8)}$ on the physical properties and reactivity of nickel/alumina impregnated catalysts.

\section{Experimental}

\subsection{Preparation}

Nickel/alumina catalysts were prepared using the vapor deposition and gas phase reduction methods. Spherical alumina of $3.5 \mathrm{~mm}$ diameter (JRC-ALO-1 supplied by Catalysis Society of Japan, Table 1) was used as the support and anhydrous nickel chloride was used as the source of nickel.

The apparatus used for catalysts preparation by the gas phase method is illustrated in Fig. 1. Reactor (10) is of a mullite tube of $35 \mathrm{~mm}$ internal diameter and $1000 \mathrm{~mm}$ length, to which inlet (B) for carrier argon and inlet (A) for argon or for hydrogen are attached. To prevent sintering of ALO-1, all gases were dried by passing them through silica gel columns (4) and dry icemethanol traps (5). A support holder (8) and a

Table 1 Physical Properties of JRC-ALO-1

\begin{tabular}{ll}
\hline Form & white sphere \\
Average diameter $[\mathrm{mm}]$ & 3.5 \\
Composition & $\eta+\gamma$-alumina \\
BET surface area $\left[\mathrm{m}^{2} \cdot \mathrm{kg}^{-1}\right]$ & $1.69 \times 10^{510}$ \\
Modal pore diameter $[\mathrm{nm}]$ & $9.0^{11)}$ \\
Specific pore volume $\left[\mathrm{m}^{3} \cdot \mathrm{kg}^{-1}\right]$ & $6.70 \times 10^{-411)}$ \\
\hline
\end{tabular}




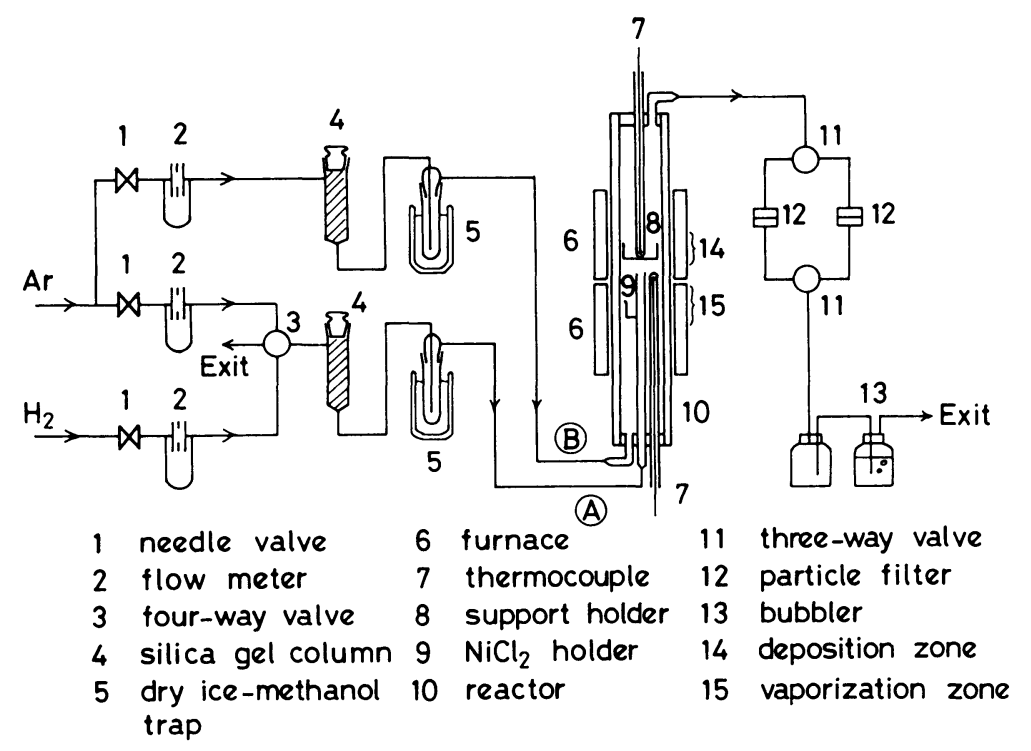

Fig. 1 Schematic Diagram of Experimental Apparatus

nickel chloride holder (9) are attached at the upper part (14, deposition zone) of reactor (10) and at its lower part (15, vaporization zone), respectively. Support holder (8) is made of an alumina tube and a nickel net, and nickel chloride holder (9) is made of a nickel net. Temperatures of deposition zone (14) and vaporization zone (15) are maintained at the desired levels by electric furnaces (6). The temperature of each zone is monitored by thermocouple (7).

Operation procedures of deposition zone (14) are illustrated in Fig. 2. Conditions used for catalyst preparation are shown in Table 2 . The nickel chloride vapor evolved in vaporization zone (15) at $1073 \mathrm{~K}$ was permitted to flow through deposition zone (14), in which alumina holder (8) was suspended. In all experiments, the partial pressure of nickel chloride vapor at deposition zone (14) was $0.72 \pm 0.08 \mathrm{kPa}$ estimated from the material balance of nickel chloride. Three types of program for deposition zone atmosphere were applied as illustrated in Fig. 2. As an example, the procedure of type $\mathrm{I}$ is described below. During the temperature elevation of the deposition zone, hydrogen was introduced from inlet (A). After attaining the desired temperature, $T_{\mathrm{d}}$, hydrogen from (A) was exchanged with argon by manipulating the four-way valve (3). After a certain elapse of time, $t_{\mathrm{d} 2}$, argon from (A) was replaced by hydrogen, which flowed through for a period of time, $t_{\mathrm{r}}$. Under such conditions, unsupported nickel fine particles were also formed, and they were collected by filtration (12) of the flue gas from reactor (10). The particles were formed by gas phase reduction of nickel chloride vapors in the bulk gas phase of

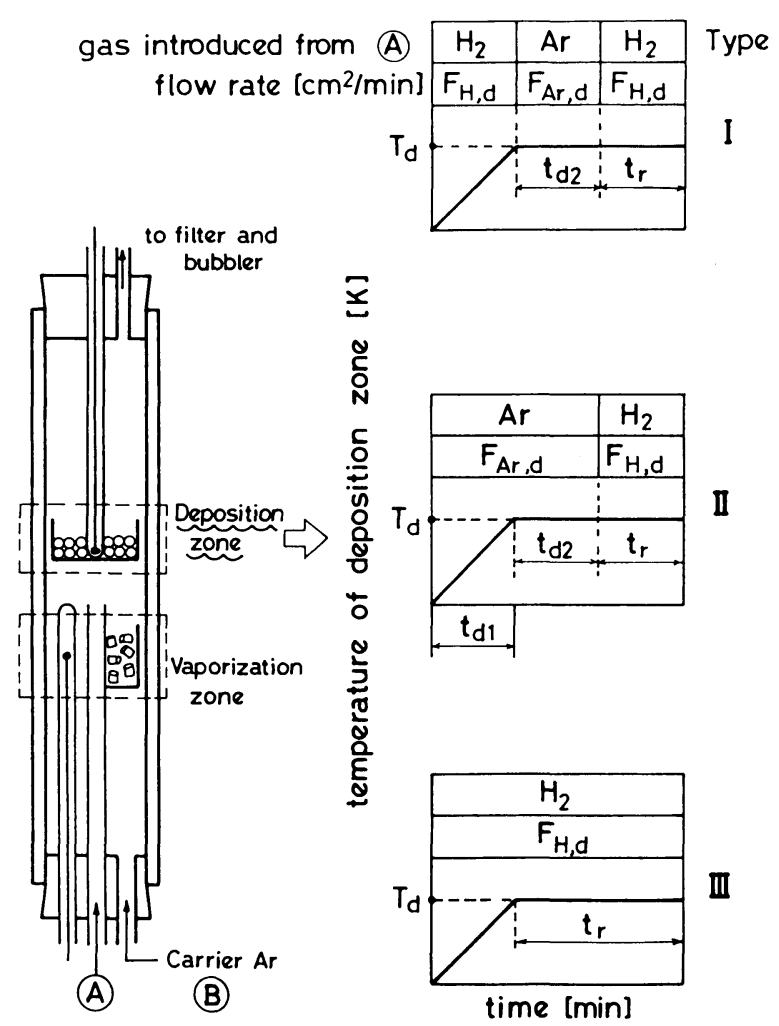

Fig. 2 Operation Procedure of Deposition Zone

deposition zone (14).

After cooling down to room temperature, samples were taken out separately from reactor (10), i.e., from the upper portion of the holder (upper sample) and from the lower portion of the holder (lower sample). 
Table 2 Preparation Conditions

\begin{tabular}{|c|c|c|c|c|c|c|c|c|c|}
\hline \multirow{2}{*}{$\begin{array}{l}\text { Run } \\
\text { No. }\end{array}$} & \multicolumn{7}{|c|}{ Deposition zone } & \multicolumn{2}{|c|}{$\mathrm{Ni}$ content [wt\%] } \\
\hline & $\begin{array}{c}\text { Type } \\
\text { (shown in Fig. 2) }\end{array}$ & $\begin{array}{c}T_{\mathrm{d}} \\
{[\mathrm{K}]}\end{array}$ & $\begin{array}{r}F_{\mathrm{Ar}, \mathrm{d}} \\
{[\mathrm{cm}}\end{array}$ & $\left.\mathrm{n}_{\mathrm{H,d}}^{-1}\right]$ & $t_{\mathrm{d} 1}$ & $\begin{array}{c}t_{\mathrm{d} 2} \\
{[\mathrm{~min}]}\end{array}$ & $t_{\mathrm{r}}$ & upper sample & lower sample \\
\hline G2 & III & 1073 & - & 100 & - & - & 160 & $(0.17)^{*}$ & $(0.17)^{*}$ \\
\hline G3 & I & 1073 & 100 & 100 & - & 90 & 90 & 1.43 & 1.73 \\
\hline G5 & I & 1033 & 100 & 100 & - & 90 & 90 & 1.73 & 1.86 \\
\hline G6 & I & 1013 & 100 & 100 & - & 90 & 90 & 1.96 & 2.20 \\
\hline G7 & I & 1073 & 100 & 100 & - & 30 & 90 & 1.38 & 1.43 \\
\hline Gl1 & II & 1073 & 50 & 50 & 195 & 60 & 60 & 2.49 & 3.15 \\
\hline G12 & II & 1073 & 50 & 50 & 196 & 0 & 60 & 1.70 & 2.42 \\
\hline $\mathrm{G} 13$ & II & 1073 & 50 & 50 & 201 & 20 & 60 & 1.89 & 2.77 \\
\hline Gl4 & I & 1013 & 50 & 50 & - & 30 & 60 & 1.23 & 1.50 \\
\hline
\end{tabular}

* The product was not fractionated.
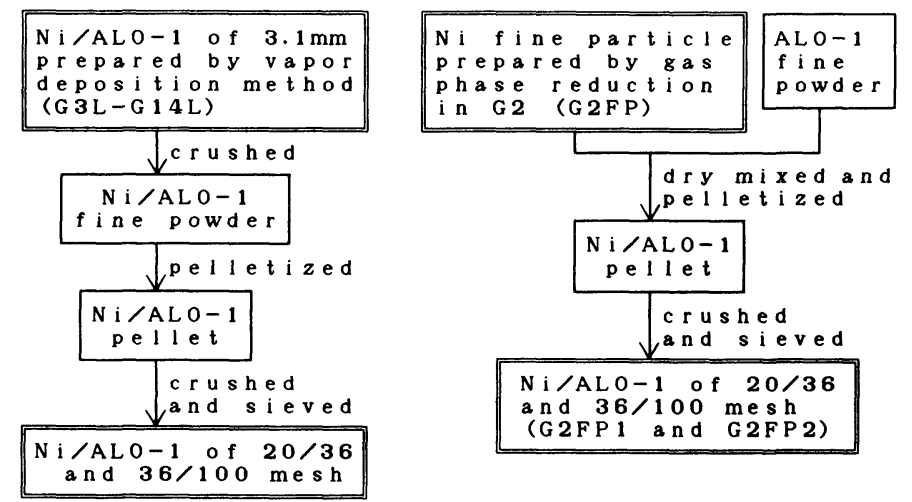

Fig. 3 Preparation Procedure of Nickel/Alumina used for Reaction Experiment

\subsection{Physical Properties}

The nickel content of each catalyst was determined by titration of the nickel(II) ions in the sample solution prepared by dissolving the nickel of the catalyst in hydrochloric acid and by filtering.

Transmission electron microscopy (TEM, Hitachi $\mathrm{H}-700 \mathrm{H}$ ) was used to determine the nickel particle diameters and their distribution in the catalyst. The acceleration voltage of the electron beam was $200 \mathrm{kV}$ and the filament current was $20 \mu \mathrm{A}$. About 100 to 200 nickel particles were measured for inspection of the diameters using at least ten enlarged photographs of $36000 \times$.

\subsection{Hydrogenation of Benzene}

Catalytic hydrogenation of benzene in the gas phase was undertaken to investigate the activity of the catalysts prepared in this study. Samples for the experiments were prepared as illustrated in Fig. 3. Samples in the range from 20 to 36 mesh (average diameter $0.63 \mathrm{~mm}$ ) were mainly used.

About $100 \mathrm{mg}$ of the catalyst was packed in the reactor (Pyrex tube of $10 \mathrm{~mm}$ internal diameter) and was pretreated in a stream of hydrogen at $673 \mathrm{~K}$ for $1 \mathrm{~h}$. After cooling down to reaction temperature $(483 \mathrm{~K})$, the reactant gases were al- lowed to flow through the catalyst bed. The partial pressure of benzene was $2.3 \mathrm{kPa}$ and that of hydrogen was $70.9 \mathrm{kPa}$. Space velocity was about $40 \mathrm{~s}^{-1}$. Reactor effluent samples were injected into a gas chromatograph via a microvolume sampling valve to measure the rate of reaction.

\section{Results and Discussion}

Table 3 gives the physical properties and reactivity of the catalysts thus prepared: nickel/ alumina catalysts by vapor deposition method (G3L to G14L) and by gas phase reduction method (G2FPl and G2FP2). The average nickel particle diameters of the catalysts prepared by vapor deposition method were from 500 to $650 \mathrm{~nm}$, while those of the catalysts by gas phase reduction method were about $120 \mathrm{~nm}$. The nickel surface area per unit mass of catalyst $\left(S_{\mathrm{N}_{\mathrm{i}}}\right)$ presented in Table 3 was calculated from the nickel content and from the surface mean diameter of nickel particles $\left(\bar{D}_{\mathrm{p} 32}\right)$ assuming that the surface of the nickel particles is smooth.

Transmission electron micrographs of G11L (nickel/alumina by vapor deposition), G2FP (nickel fine particle by gas phase reduction in G2), and impregnated nickel/alumina (nickel content 
Table 3 Characteristics of Catalysts

\begin{tabular}{|c|c|c|c|c|c|}
\hline Sample & $\begin{array}{c}\text { Nickel content } \\
{[w t \%]}\end{array}$ & $\begin{array}{c}\bar{D}_{\mathrm{p} 32} \\
{[\mathrm{~nm}]}\end{array}$ & $\begin{array}{c}S_{\mathrm{Ni}} \\
{\left[\mathrm{m}^{2} \cdot \mathrm{kg}^{-1}\right]}\end{array}$ & $\begin{array}{c}r_{1} \times 10^{5} \\
{\left[\mathrm{~mol} \cdot \mathrm{kg}^{-1} \cdot \mathrm{s}^{-1}\right]}\end{array}$ & $\begin{array}{c}r_{1} / S_{\mathrm{Ni}} \times 10^{6} \\
{\left[\mathrm{~mol} \cdot \mathrm{m}^{-2} \cdot \mathrm{s}^{-1}\right]}\end{array}$ \\
\hline G2FPl ${ }^{* 1}$ & 1.58 & 123 & 87.1 & 9.11 & 1.05 \\
\hline G2FP2*1 & 2.99 & 123 & 165 & 18.4 & 1.12 \\
\hline$G 3 L^{* 2}$ & 1.73 & 511 & 23.0 & 5.19 & 2.26 \\
\hline G5L & 1.86 & 582 & 21.7 & 5.38 & 2.48 \\
\hline G6L & 2.20 & 548 & 27.2 & 6.40 & 2.35 \\
\hline G7L & 1.43 & 500 & 19.4 & 5.63 & 2.90 \\
\hline G11L & 3.15 & 651 & 32.8 & 11.6 & 3.54 \\
\hline G12L & 2.42 & 529 & 31.0 & 22.5 & 7.26 \\
\hline G13L & 2.77 & 640 & 29.3 & 21.9 & 7.47 \\
\hline G14L & 1.50 & 547 & 18.6 & 7.89 & 4.24 \\
\hline $\begin{array}{l}\text { Impregnated } \\
\text { nickel/aluminas }\end{array}$ & - & - & - & - & 0.90 \\
\hline
\end{tabular}

${ }_{1}^{*}$ prepared by dry kneading a mixture of nickel fine particle in G2 (G2FP) and ALO-1 fine powder.

*2 "L" refers to the lower sample.

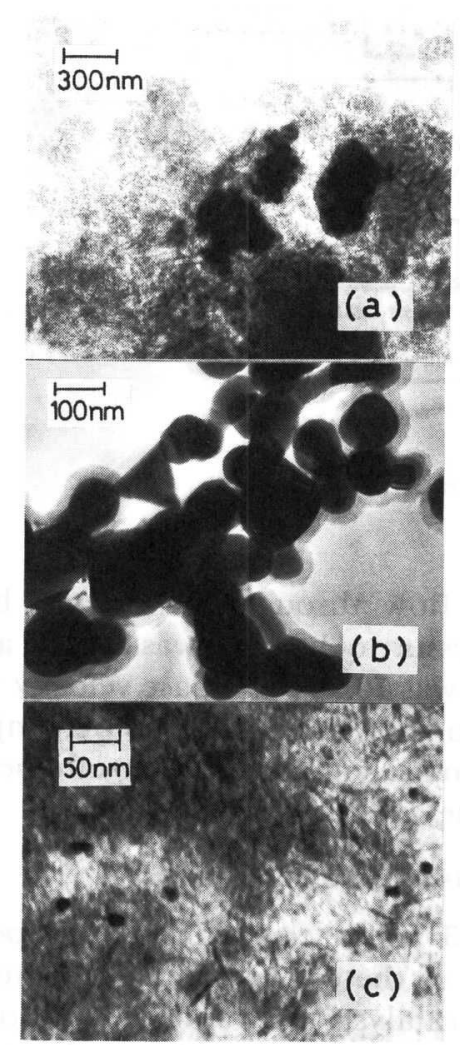

Fig. 4 Transmission Electron Micrographs:

(a), G11L (nickel/alumina by the vapor deposition); (b), G2FP (nickel fine particle by the gas phase reduction in G2); (c), impregnated nickel/alumina (nickel content $1.16 \mathrm{wt} \%$ ). ${ }^{5}$ ) Black images represent nickel particles.

$1.16 \mathrm{wt} \%)^{5)}$ are shown in Fig. 4. The black images are nickel particles. The surface of the nickel particles of the typical vapor deposition nickel/ alumina $(\mathrm{G} 11 \mathrm{~L})$ consists both of convex and concave parts, whereas the surfaces of gas phase reduced nickel fine particles and those of nickel particles of the impregnated catalysts are smooth.

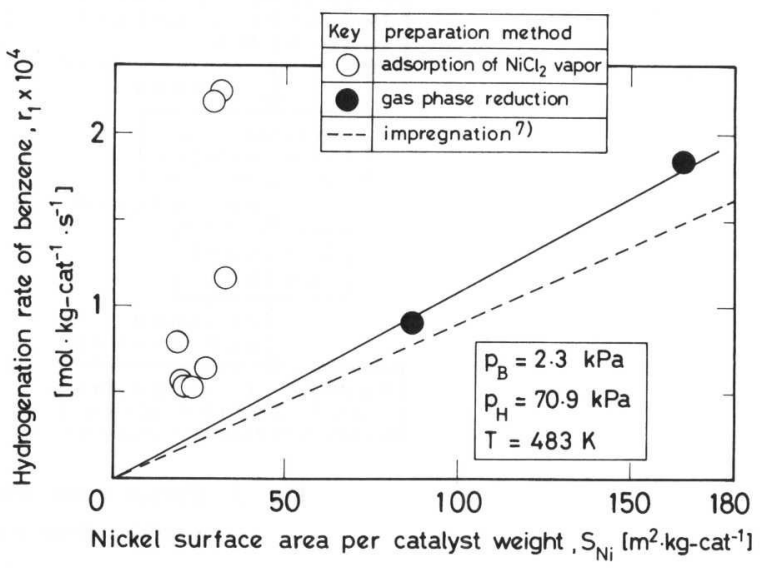

Fig. 5 Hydrogenation Rate of Benzene as a Function of Nickel Surface Area

As described in section 2.3, catalyst samples of 20-36 mesh and of 36-100 mesh were used to measure the reaction rate. Since the results of the reaction using both samples were substantially the same, intracatalyst diffusion was negligible in this study. Figure $\mathbf{5}$ shows the rate of benzene hydrogenation per unit mass of catalyst as a function of nickel surface area per unit mass of catalyst. The slope of the solid line drawn in Fig. $\mathbf{5}$ is not so different from that of the dotted line, i.e., there is no significant difference in the reaction rate per unit surface area of nickel (listed in the last row of Table 3 ) between the catalyst by gas phase reduction and that by impregnation. The reaction rate of the catalyst prepared by vapor deposition, on the other hand, is 3 to 8 times as large as that of the catalyst prepared by impregnation. The factors from 3 to 8 seem to be caused by the characteristics of the nickel particle surface observed by TEM inspection as shown in Fig. 4. In other words, either the presence of uneven surface or the increase in turnover frequency may have caused it. Nishiyama et al.12),13) reported that 


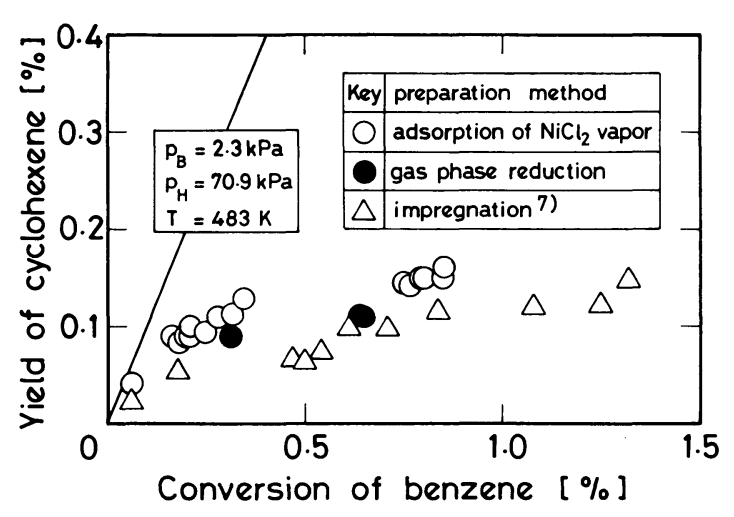

Fig. 6 Yield of Cyclohexene as a Function of Conversion of Benzene

turnover frequencies of hydrogen-deuterium exchange and ethylene hydrogenation on supported metal (palladium, platinum, and rhodium) catalysts were promoted by ultrahigh vacuum treatment. They proposed a scheme, in which minute roughness of the metal particle surface by ultrahigh vacuum treatment brought about this promotion.

A pulse method ${ }^{14)}$ was used to measure the amount of hydrogen chemisorption of the catalysts. The results showed a very small amount of hydrogen chemisorption (near the lower limit of detection) corresponding to the TEM data.

Reaction products were cyclohexene and cyclohexane. Decomposition products, such as methane, were not found. This may be responsible for the low levels of benzene conversion from 0.1 to $1 \%$. Figure 6 shows the yield of cyclohexene as a function of benzene conversion. The result shows the following order of cyclohexene: vapor deposition $>$ gas phase reduction $>$ impregnation. Hayashi et al.4) reported that nickel ultrafine particles prepared by gas evaporation method showed improved selectivity of cyclooctene for hydrogenation of 1,3-cyclooctadiene.

\section{Conclusions}

Studies on nickel/alumina catalysts prepared by vapor deposition and gas phase reduction were undertaken to determine the effects of the methods used, including impregnation, on the reactivity of nickel/alumina catalysts. The following results were obtained:

(1) There was no significant difference in the reaction rate per unit surface area of nickel between the catalyst prepared by gas phase reduction and that prepared by impregnation.

(2) The reaction rate of the catalyst prepared by vapor deposition was 3 to 8 times greater than that of the catalyst prepared by impregnation.
This difference seems to be caused by the characteristics of the nickel particles whose surface was uneven effected by vapor deposition or whose activity per unit surface area was higher.

(3) Order of selectivity for cyclohexene was as follows: vapor deposition $>$ gas phase reduction $>$ impregnation.

\section{Acknowledgment}

The authors wish to thank Professor S. Morooka of Kyushu University and Associate Professor K. Ikemizu of Tohwa University for their valuable advice.

The authors also gratefully acknowledge financial support from a Grant-in-Aid for Scientific Research of the Ministry of Education, Science and Culture, Japan (No. 61750893, 1986).

\section{Nomenclature}

$\bar{D}_{\mathrm{p} 32}=$ surface mean diameter of nickel particle $\quad[\mathrm{nm}]$

$F_{\mathrm{Ar}, \mathrm{d}}=$ gas flow rate of argon introduced from inlet (A) in Fig. $2 . \quad\left[\mathrm{cm}^{3} \cdot \mathrm{min}^{-1}\right]$

$F_{\mathrm{H}, \mathrm{d}}=$ gas flow rate of hydrogen introduced from inlet (A) in Fig. $2 . \quad\left[\mathrm{cm}^{3} \cdot \mathrm{min}^{-1}\right]$

$p_{\mathrm{B}}=$ partial pressure of benzene $\quad[\mathrm{kPa}]$

$p_{\mathrm{H}}=$ partial pressure of hydrogen $\quad[\mathrm{kPa}]$

$r_{1}=$ benzene hydrogenation rate per unit mass of catalyst $\left[\mathrm{mol} \cdot \mathrm{kg}^{-1} \cdot \mathrm{s}^{-1}\right]$

$S_{\mathrm{Ni}}=$ nickel surface area per unit mass of catalyst $\left[\mathrm{m}^{2} \cdot \mathrm{kg}^{-1}\right]$ $T=$ reaction temperature

$T_{\mathrm{d}}=$ temperature of deposition zone

$t_{\mathrm{d} 1}=$ deposition time during temperature elevation [min] $t_{\mathrm{d} 2}=$ deposition time at $T_{\mathrm{d}}$

[min]

$t_{\mathrm{r}}=$ reduction time [min]

\section{References}

1) Morooka, S., Kobata, A., Yasutake, T., Ikemizu, K., Kato, Y., Kagaku Kogaku Ronbunshu, 13, 481 (1987).

2) Tsugo, Y., Ooi, H., Yano, M., Harano, Y., Proceedings of World Congress III of Chemical Engineering, Vol. 4, 310 (1986).

3) Noda, M., Shinoda, S., Saito, Y., J. Chem. Soc. Jpn., 1017 (1984).

4) Hayashi, T., Nagayama, T., J. Chem. Soc. Jpn., 1050 (1984).

5) Uemura, Y., Hatate, Y., Ikari, A., Sekiyu Gakkaishi, 29, 143 (1986).

6) Uemura, Y., Hatate, Y., Ikari, A., J. Chem. Eng. Japan, 19, $560(1986)$

7) Uemura, Y., Hatate, Y., Ikari, A., Sekiyu Gakkaishi, 30, 53 (1987).

8) Uemura, Y., Hatate, Y., Ikari, A., J. Chem. Eng. Japan, 20, 117 (1987).

9) Uemura, Y., Hatate, Y., Ikari, A., J. Chem. Eng. Japan, 20, 563 (1987).

10) Data-JRC-0001, Hattori, T., Shokubai (Catalyst), 22, 115 (1980).

11) Data-JRC-0002, Mukaida, K., Shokubai (Catalyst), 22, 116 (1980). 
12) Nishiyama, S., Matuura, S., Morita, H., Tsuruya, S., Masai, M., Appl. Catal., 15, 185 (1985).

13) Nishiyama, S., Yoshida, T., Tsuruya, S., Masai, M., Preprints for 20th Autumn Meeting of SCEJ, SC303
(1987).

14) Yasui, E., Haga, F., Preprints for 5th Annual Symposium on Reference Catalyst, Hokkaido, Aug., 13 (1983).

要 旨

\title{
気相法により調製した担持ニッケル触媒の反応性
}

\author{
上村 芳三, 幡手 泰雄, 碇 醇
}

鹿児島大学工学部化学工学科, 890 鹿児島市郡元 1-21-40

担体として, 直径約 $3.5 \mathrm{~mm}$ の球状多孔質アルミナ（触媒学 会参照触媒 JRC-ALO-1, Table 1 参照）を、ニッケル源とし て無水塩化ニッケルを用いて, 気相担持法 (vapor deposition method)および気相還元法 (gas phase reduction method)によっ て調製したニッケル/アルミナ触媒を用いてベンゼンの水素化 を行い，調製法が反応性に及ぼ影響を検討した。併せて，こ れまでにわれわれが種々の操作条件の影響を検討してきた含浸 法ニッケル/アルミナ触媒 ${ }^{5)}$ ９) に関する結果と比較, 検討を 行った。

気相法触媒の調製は, Fig. 1 に示すような装置によって行っ た。担持用反応器本体は, 内径 $35 \mathrm{~mm}$, 長さ $1000 \mathrm{~mm}$ のムラ イト管の底部にキャリヤーアルゴンガス導入口（B ）, 中央部 にアルゴンガス拉よび還元用水素ガス導入口（A ）, 頂部にガ ス出口を取り付けたもので構成されており, 反応器下部は, 塩 化ニッケル蒸発部（15）, 上部は，担持部（14）となっている。 担持部（14）の温度および雾囲気プログラムを Fig. 2 に，調 製条件の詳細を Table 2 に示す。1073 K に保った蒸発部（15） から発生する塩化ニッケル蒸気を $1013 \mathrm{~K}$ から $1073 \mathrm{~K}$ の間の 所定の温度に保った担持部（14）に導いて直径 $3.5 \mathrm{~mm} の$ ALO-1に吸着させた後, 担持部（14）に水素を流して還元し, 気相担持ニッケル/アルミナ触媒を得た。気相担持触媒の水素 還元の際, 塩化ニッケル蒸気と水素が接触するので気相還元に よるニッケル微粒子も生成した。これらの粒子は, 反応管出口 に設置したフィルター（12）によって捕集した。

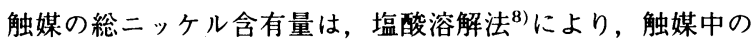
ニッケル粒子径は, 透過型電子顕微鏡法 ${ }^{8)}$ により, 測定した。 種々の調製条件で得たニッケル/アルミナ触媒の活性を比較す るため Fig. 3 に示すような方法により調製した反応用試料を
用いて, ベンゼンの気相接触水素化を行った。

Table 3 に，今回調製した気相担持ニッケル/アルミナ （G3L-G14L）と気相還元ニッケル微粒子を用いたニッケル/ア ルミナ（G2FP1 および G2FP2）の物性および反応性を示す。 気相還元ニッケル粒子の平均径 $\left(\bar{D}_{\mathrm{p} 32}\right)$ は, 約 $120 \mathrm{~nm}$ である のに対し，気相担持ニッケル/アルミナのニッケル粒子は， 500 〜 650 nm と約 5 倍の大きさである。Fig. 4 に示した TEM 写 真より, 気相担持触媒のニッケル粒子の表面が凸凹であるのに 対し, 気相還元ニッケル微粒子および含浸法触媒の表面は, な めらかであることがわかる。Fig. 5 に, 単位触媒質量あたり のベンゼン水素化速度対単位触媒質量あたりのニッケル表面積 $\left(\bar{D}_{\mathrm{p} 32}\right.$ およびニッケル含有量から算出）のプロットを示す。気 相還元触媒による結果（実線）と，含浸法触媒のそれ（破 (線) $)^{7)}$ には, 大きな差がない。一方, 気相担持ニッケル/アルミ ナのニッケル表面積あたりの反応速度は，含浸法よりかなり大 きく, 3 倍から 8 倍であった。気相担持触媒において二ッケル 表面積あたりの反応速度がこのように大きい理由としては，気 相担持法触媒にのみ見られたニッケル粒子表面の凸山が考えら れる。即ち，実際の表面積がニッケル粒子径およびニッケル含 有量から求めたものより大きいことによるものか，あるいは， 表面の性質が含浸法および気相還元法とは異なりターンオー バー数が大きくなっているかのいずれかであると考えられる。 ベンゼン水素化により，シクロヘキセンおよびシクロヘキサン が生成した。Fig. 6 に, シクロヘキセンの収率をベンゼン転 化率に対してプロットした図を示す。シクロヘキセン選択性は, 以下のような序列を示した。

気相担持法 $>$ 気相還元法 $>$ 含浸法

\section{Keywords}

Benzene, Hydrogenation, Nickel catalyst, Supported catalyst, Vapor deposition 